1969. Late Cenozoic palynology. Pp. 337-438. In: R. H. Tschudy \& R. A. Scott (Editors), Aspects of Palynology. Wiley-Interscience, N.Y.

Löve, J. D. 1961. Split Rock Formation (Miocene) and Moonstone Formation (Pliocene) in central Wyoming. U. S. Geol. Surv. Bull. 1121-I: 11-139.

MacGinitie, H. D. 1933. The Trout Creek flora of southeastern Oregon. Publ. Carnegie Inst. Wash. 416.

Muller, J. 1970. Palynological evidence on early differentiation of angiosperms. Biol. Rev. 45: $417-450$.

Newberry, J. S. 1896. Flora of the Amboy Clays. U. S. Geol. Surv. Monograph 26: 1-260.

Philipson, W. R. 1953. The relationships of the Compositae particularly as illustrated by the morphology of the inflorescence in the Rubiales and the Campanulatae. Phytomorphology 3: 391-404.

Pokrovskaya, I. M., ed. 1956. Atlas of Oligocene spore-pollen complexes of various areas. U.S.S.R. Vses. Geol. Inst. Materialy, new ser. 16. Moscow.

Raven, P. H. 1973. The origin of the alpine and subalpine floras of New Zealand. New Zealand J. Bot. 11: 177-200.

— \& D. I. Axelrod. 1974. Angiosperm biogeography and past continental movements. Ann. Missouri Bot. Gard. 61: 539-673.

Rendle, B. 1938. The Classification of Flowering Plants, vol. 2, ed. 2. Cambridge Univ. Press, London.

Saporta, G, de. 1862. Études sur la vegetation de Sud-Est de la France à l'epoque tertiare. Ann. Sci. Nat. Bot., ser. 4, 17: 191-311.

Segal, R. 1965. New fossil fruit (Compositae) from the Pliocene of western Kansas. Amer. Midl. Nat. 73: 430-432.

Skvarla, J. J., B. L. Turner, V. C. Patel \& A. S. Tomb. 1977. Pollen morphology in the Compositae and in morphologically related families. Pp. 141-248. In: V. H. Heywood, J. B. Harborne, \& B. L. Turner (Editors), The Biology and Chemistry of the Compositae. Academic Press, London.

Small, J. 1919. Fossil Compositae. Pp. 245-258. In: The Origin and Development of the Compositae. New Phytologist Reprint, no. 11. London.

Sprague, T. A. 1927. The morphology and taxonomic position of the Adoxaceae. J. Linn. Soc., Bot. 47: 471-487.

Stebbins, G. L., Jr. 1977. Developmental and comparative anatomy of the Compositae. Pp. 91-109. In: V. H. Heywood, J. B. Harborne, \& B. L. Turner (Editors), The Biology and Chemistry of the Compositae. Academic Press, London.

Stuessy, T. F. 1977. Systematics of the Heliantheae. Pp. 621-671. In: V. H. Heywood, J. B Harborne, \& B. L. Turner (Editors), The Biology and Chemistry of the Compositae. Academic Press, London.

Subramanyam, K. 1951. On the probable origin of the unilocular ovary of the Compositae from the Stylidiaceae. Proc. Indiana Acad. Sci., sect. B, 33: 327-330.

Turner, B. L. 1977. Fossil history and geography. Pp. 21-39. In: V. H. Heywood, J. B. Harborne, \& B. L. Turner (Editors), The Biology and Chemistry of the Compositae. Academic Press, London.

Verlaque, R. 1977. Importance du fruit dans la determination des Dipsacaceae. Bull. Soc. Bot. France 124: 515-527.

\title{
NOTICE
}

\section{AGAIN AVAILABLE: EVOLUTION AND CLASSIFICATION OF FLOWERING PLANTS}

By Arthur Cronquist. Originally published by Houghton Mifflin in 1968, the book has recently been out of print. A new printing, in paperback, is being made for the author by Allen Press. It is offered for sale by the New York Botanical Garden for $\$ 5$ at the Garden. For mail orders add $\$ 1$ for the cost of handling and postage, surface mail. Make checks payable to the New York Botanical Garden and send to Publications Office, New York Botanical Garden, Bronx, New York 10458. 